\title{
A PROGRAM OF THEIR OWN: THE DESIGN AND EVOLUTION OF AN UNDERGRADUATE DEGREE PROGRAM FOR POLICE OFFICERS IN ONTARIO
}

\author{
\begin{tabular}{l|} 
NTIN DECKHA \\
UNIVERSITY OF GUELPH-HUMBER
\end{tabular}
}

\begin{abstract}
In the late 1990s and early 2000s, the Toronto Police Service was exploring how to increase access to higher education to its officers. The service saw higher education as salient to its organizational imperatives of professionalization, increased public legitimacy and credibility, and enhanced academic recognition of police professional learning. To realize this mission, the Toronto Police Service entered into a higher education partnership with the University of Guelph and Humber Institute of Technology and Advanced Learning under its then-new joint venture, the University of Guelph-Humber. The University of Guelph-Humber designed an accredited higher education pathway for Toronto Police personnel that also gave academic credit for past professional learning and increased educational access by offering blended course delivery. Based on semi-structured interviews with key educational administrators at the University of Guelph-Humber, Humber Institute of Technology and Advanced Learning, and the Toronto Police Service, this article narrates the origins of this higher education pathway-a Bachelor of Applied Arts in Justice Studies. In addition, it describes how this pathway evolved to include non-uniform Toronto police personnel, other police services, and expanded further to include learners from the larger justice and public safety fields. The exploration is situated in a larger discussion about the relationship between higher education, professionalization and legitimacy, and the potential of partnerships between higher educational institutions and professions in Canada. Keywords: higher education; professionalization; police; adult learning; educational partnerships; credentialization; educational access; undergraduate degree
\end{abstract}

\section{Résumé}

À la fin des années 1990 et au début des années 2000, le Service de police de Toronto explorait les moyens d'améliorer l'accès à l'éducation postsecondaire pour ses officiers. Le Service voyait l'éducation postsecondaire comme un outil pour atteindre ses buts organisationnels, dont la professionnalisation, l'accroissement de la légitimité et de la crédibilité auprès du public et l'amélioration de la reconnaissance de la formation policière dans le milieu de l'éducation. Afin de réaliser cette mission, le Service de police de Toronto s'est engagé dans un partenariat avec l'Université de Guelph et le Humber Institute of Technology and Advanced Learning dans le cadre de la toute nouvelle Université de Guelph-Humber. L'Université de Guelph-Humber a élaboré un programme d'études postsecondaires agréé sur mesure pour le personnel de police de Toronto, reconnaissant la formation professionnelle antérieure et offrant un mode de prestation de cours hybride pour plus d'accessibilité. Fondé sur des entrevues semi-structurées avec des administrateurs et administratrices de l'Université de Guelph-Humber, du Humber Institute of Technology and Advanced Learning et du Service de police de Toronto, le présent article raconte les origines de ce programme de baccalauréat en arts appliqués en études juridiques. Par ailleurs, il décrit comment le programme a évolué afin d'inclure le personnel civil du Service de police de Toronto, les autres services policiers, et également les étudiant(e)s des secteurs de la justice et de la sécurité publique. Cette exploration se situe dans une discussion plus vaste au sujet des rapports entre éducation postsecondaire, professionnalisation et légitimité et des partenariats potentiels entre les établissements postsecondaires et les professions au Canada.

Mots-clés : éducation postsecondaire, professionnalisation, police, formation des adultes, partenariats éducatifs, agrément, accès à l'éducation, baccalauréat 


\section{Introduction}

In the late 1990s and early 2000s, the Toronto Police Service (TPS) was exploring how to increase access to higher education for its officers, particularly its more senior ones, many of whom only had a high school diploma. Undergirding this pursuit for greater access to higher education were a number of interconnected factors. These included the professionalization of policing; increasing credibility and legitimacy in the eyes of the public and the various elements of the justice system that police officers dealt with, such as the courts. Additional factors included enhancing the academic recognition of the training and education that police underwent and, dealing with the reality that younger and newer police officers who were being hired possessed greater higher education than the superior ranking personnel who were supervising them.

As such, this paper shows how the TPS formed a partnership with a higher education institution in order to deepen its organizational imperative to professionalize and enhance its perceived credibility and legitimacy in the eyes of the public as well as with the larger criminal justice system. Specifically, the paper will argue that:

1. The TPS sought a partnership with a higher education institution as part of its twinned mission to professionalize and to credentialize.

2. This professionalizing project, to adapt Suddaby and Viale's (2011) term, includes aspirations to increase its legitimacy with the public, including credibility and trust.

3. However, given the specific organizational concerns of the TPS, such as how to encourage long-standing and high-ranking officers without formal, higher education credentials to pursue a higher education qualification, the TPS also needed a unique higher education structure, which involved significant consideration of police training, work experience and prior learning assessment and recognition (PLAR).

First, it would be helpful to clarify what I mean by professionalization. For Ackroyd (1996), "social and medical services professions have grown hugely with the development of the welfare state: in particular, teaching, social work, and the criminal justice system" (p. 610). These social and medical services professions, Ackroyd continues, "also have a central organization which is able to exert some control over the education and licensing of practitioners and, through this, to control the supply of labour on the labour market" (p. 610). Ackroyd identities the use of education as a part of what professions do in the course of controlling who gets to effectively practise that profession, what theorists describe as labour market or occupational closure (see Abbott, 1988; Evetts, 2006; McCann et al., 2013; Pohler \& Willness, 2014).

As Evetts (2006) elaborates: "The process of occupational closure will result in the monopoly supply of the expertise and the service, and probably also in privileged access to salary and status as well as in definitional and control rewards for practitioners" (p. 137). Indeed, in the city of Toronto, the TPS has a monopoly of providing services to maintain public safety and social order and, through various legislated acts, such as the Police Services Act, is granted certain authority and power which contribute to Evetts's points about salary, status and rewards.

Yet, it would seem by these descriptions that the police, and the TPS as one example, is already a profession that has power, authority, status, privileged access to rewards, occupational closure, and the ability to, in part, control the "education and licensing of practitioners" (Ackroyd, 1996, p. 216). Why, then, would it pursue a partnership with a higher education institution? DiMaggio and Powell (1983) "interpret professionalization as the collective struggle of members of an occupation to define the conditions and methods of their work...to establish a cognitive base and legitimation for their occupational autonomy" (p. 152). Moreover, DiMaggio and Powell continue, one key aspect of professionalization is "the resting of formal education and of legitimation in a cognitive base produced by university specialists" ( $p$. 152).

Furthermore, to connect the aim to professionalize with credentialization, Brown (2001) embeds Collins's (1979) work on credential stratification in society, who demonstrates that "competition among status groups [is] the primary cause of credentialed stratification in professional and bureaucratic labor markets" (Brown, 2001, p. 24). Thus, in the TPS quest for educational legitimacy is also a related one of the credentialization and legitimization of its own police-based knowledge against other status groups in the criminal justice system, such as judges and lawyers.

Hence, I submit that the TPS felt an occupational imperative to extend its professionalizing project further 
and strengthen its perceptions of credibility, public trust and legitimacy. Unlike further internal police training, an accredited higher education institution and its cadre of educators could design a curriculum to supposedly produce this cognitive base that DiMaggio and Powell (1983) discuss and offer a legitimate credential to strengthen police legitimacy.

Second, the United Kingdom has seen a robust discussion of the potential role of higher education of police officers and partnerships with higher education institutions, with successive governmental efforts in England and Wales to standardize police education. Wood and Tong (2009) explore the dynamics of delivering a Student Officer Programme, a collaboration between a university department and a police service in the UK. Christopher (2015) examines the virtues of mandating that potential police officers complete a higher education credential before entering the field (thus a pre-entry scheme) and uses the partnership between Leicestershire Police and de Montfort University as an example. Ramshaw and Soppitt (2018) and Williams et al. (2019) seek to connect the role of higher education with the establishment of the College of Policing and the implementation of a Police Educational Qualification Framework (PEQF) for England and Wales. Significantly, the College of Policing sets out to standardize police training in England and Wales to include pre-entry pathways for potential recruits, pathways for those with other degrees as well as post-join pathways for experienced officers (Ramshaw \& Soppitt, 2018).

Moreover, Fielding (2018) juxtaposes these discussions of police-higher education relationships within a larger examination of police professionalism and professionalization in the UK. Huisjes et al. (2018) offer a Dutch examination, exploring the historical contours of police education and professionalization in the Netherlands, broaching a larger discussion of competencies of the reflective professional. Meanwhile, American examinations by Cordner $(2016,2019)$ have mainly demonstrated the preponderance of criminal justice degree programs and the lack of higher education programs designed specifically for educating police officers in the United States. Bartkowiak-Théron (2019) further mentions professionalization in Australia and its specific partnerships between universities and police organizations.

In Ontario, Canada, de Lint (1998) and Wood (2000) variously discuss the efforts of the 1992 Strategic Plan- ning Committee on Police Training and Education to reimagine police training and education. Wood (2000) discusses the Strategic Planning Committee's proposal within the context of creating greater fiscal accountability, community and service focus within police services and designing training that emphasizes principles of flexibility, adaptability and continuous learning. Part of the Strategic Planning Committee's work included "conduct[ing] research on learning systems in other sectors, including the private sector, the teaching and nursing professions, and the Ontario and Federal governments," in their quest "to create a learning model that would be tailored to the exigencies of policing" (p. 164). More recently, Huey et al. (2017) assess the plethora of police educational programs offered in colleges and universities across Ontario and their alignment with the recruitment needs of police services.

Third, in order to facilitate access to higher education for police and other adult learners, it is important to consider research that examines how prior learning assessment (PLA) has facilitated more adult students (that is students outside of the conventional 18-to-22-year-old cohort) to complete higher education programs (Bowers \& Bergman, 2016; Boyle et al., 2018; Hayward \& Williams, 2015; Rust \& Ikard, 2016; Travers, 2012). Hayward and Williams (2015) and Rust and Ikard (2016) offer quantitative studies of the significance of prior learning assessments; namely, the formal and systematic evaluation and recognition of a student's training and education before enrolling in a higher education program, in US contexts. Bowers and Bergman (2016) embed examinations of PLA and flexible learning deliveries within a larger context of adult learners' return on investment in higher education at a time when, in the United States, those with college and university degrees have lower unemployment rates and higher income earning potential in an economy where both existing and emergent jobs demand higher education. Boyle et al. (2018) describe the efforts of one US state, Tennessee, to align its higher educational offerings with the state's workforce needs, which includes creating state-wide systematicity of PLA to allow students to transfer credit from institution to another. Travers (2012), meanwhile, surveys the transformations of PLA within emerging educational ecosystems of greater choice, self-direction, and access.

In Canada, Prior Learning Assessment and Recognition (PLAR) facilitates "transferability and mobility for learners to be admitted to college programs, receive rec- 
ognition for their prior learning in college courses or programs or for graduates to transition to programs at other post-secondary institutions" (Association of Canadian Community Colleges, 2011, p. 22). PLAR involves "the identification, documentation, assessment and recognition of learning)" that "may be acquired through formal and informal study including work and life experience, training, independent study, volunteer work, travel, hobbies and family experiences" (p. 22). PLAR effectively facilitates credentialization, and the leveraging of various forms of vocational or occupational training for potential academic credit, first via the college system and then to other postsecondary institutions, such as universities. Importantly, PLAR served as a key conduit in providing the legitimacy of existing police training and forging a pathway for higher education.

Thus, there are studies of specific jurisdictions (Boyle et al., 2018) and educational institutions (Hayward \& Williams, 2015). In addition, there is an evaluative review of the training activities of the TPS (Griffiths, 2006) as well as the earlier efforts to systematize a police learning system in Ontario (de Lint, 1998; Wood, 2000). However, what the literature lacks is a direct focus on the relationship between a Canadian police service and its endeavours to create higher educational pathways for its members, ultimately through partnership with a higher education institution, that is investigated as a process of professionalization, credentialization and legitimization. As a result, the key take home message of this paper is to show how the creation of higher education pathway for the TPS into a degree program offered by the University of Guelph-Humber provided greater legitimacy to the TPS and strengthened its aim to professionalize and credentialize.

\section{Method}

I draw on research conducted over 2016 and 2017 when I interviewed three different, yet salient, constituencies, which I call Group A, Group B, and Group C. The study proposal was submitted and received research ethics approval from the Research Ethics Board at the Humber Institute for Technology and Advanced Learning. The study proposal was also submitted to, and received approval from, the Toronto Police Service's Strategy Management Unit. Group A was composed of various educational leaders and administrators that contributed and/ or continue to contribute to the design and delivery of the partnered higher education program, an accredited Bachelor of Applied Arts (BAA) in Justice Studies. Group $B$ was comprised of past and present members of the Toronto Police Service who had been or were engaged in police training and development activities, primarily through the Toronto Police College, which designs and delivers such activities for the approximately 4700-member service in a dedicated facility. Group C, which was composed of 20 TPS service members who had pursued and completed an undergraduate degree, whether in the partnered program with the University of Guelph-Humber or through another university.

Groups A and B were initially recruited through contacting current educational administrators and training officers at the University of Guelph-Humber and the TPS, respectively. From this initial group, I used a snowball sampling approach to be referred to the people who played an instrumental role in the creation and/or administration of the University of Guelph-Humber/ TPS partnership. Group $C$ was recruited only after the TPS approved my research request as well as my information letter and invitation to participate in the study. Through the auspices of the Toronto Police College, these materials were sent to current TPS members through the Service's internal networks. After recruitment was completed, I conducted a series of semi-structured interviews that were held in person and audio-recorded. Interviewees in Group A were asked the following questions:

1. How did your institution's higher education program for police officers come to be?

2. What was and has been the relationship between your institution and TPS and their specific needs?

3. How was the program designed to meet the needs of police services such as the TPS and how has this evolved?

Interviewees in Group B were asked:

1. What gaps in existing TPS training programs (including those at the Toronto Police College) did access to higher education address for your employees?

2. How has access to a degree program to TPS employees affected the effectiveness of the TPS as an organization?

3. How has having TPS officers complete a de- 
gree program allowed TPS to realize its stated goals (in mission and value statements and in strategic plans)?

Interviewees in group B were specifically being asked about how higher education would address gaps in existing police training as well as how access to a degree program would respond to TPS organizational goals, which do include issues of professionalism, trust, service improvement and public legitimacy.

These interviews were then transcribed and then, using nVivo software, reviewed, assessed and coded against various nodes which included: credentialization, degree, delivery format, education, group-think, leadership development, learning, organization, partnership, PLAR, program breadth and expansion, recognition, recruitment of students, and a node that linked the TPS, Humber Institute of Technology and Advanced Learning, University of Guelph-Humber and Justice Studies. These nodes were chosen based on their frequency in emerging over the course of respondent discussion. This article focuses on the findings from interviews from respondents in groups $A$ and $B$. Interviews with group $C$ are excluded from this paper, as these interviews focus on the specific higher educational experiences of TPS members and will be discussed in a separate publication.

\section{Findings}

During the late 1990s-early 2000s, the TPS invested in sending some of its senior personnel to leadership development programs. One course involved a partnership between the University of Toronto's Rotman School of Management and the Ontario Association of Chiefs of Police. It "was a four-week course, cost about $\$ 12,000$ when it was originally developed and it had no academic credit at all" (B1, June 2016). Another, run in conjunction with the Ontario Provincial Police (OPP) and two American universities, was called the GOLD (Graduate Officer Leader Development) course (B1, June 2016). Beyond the relative expensive nature of these and other management and leadership development courses offered under the auspices of the Ontario Police College and the Canadian Police College, there were other limitations imposed by these courses. As B1 explains:

$[Y]$ ou could only get so many spots per year. So if you have 160-180 senior police officers and let's stay you have a turnover of, I don't know, 30\% a year, might not be that high, there is simply no way you can everybody trained. The other problem with it was, it carried no educational...credit. And the last problem was, that it was all on duty. It was training. (B1, June 2016)

B1 elaborates a number of challenges that the TPS was facing in determining educational options for its officers. While there were executive leadership opportunities, the relatively size of the cohorts was small. They were not conducive to educating large swathes of people, given that the "Toronto Police had huge number of their officers [who] didn't even have a [college] diploma" (A1, June 2016). In addition, if a senior officer pursued a leadership course, they were still on duty, thus paid; as such, their absence from their regular work duties would present staffing issues, further constraining the TPS. Moreover, as B1 underlines, there was no academic credit that was being offered. This fed into the related challenges of enhancing police legitimacy, credibility and recognition, especially in the ongoing intensification of credentialism in Canada and elsewhere (Fuller 2001; Hurley \& Sá, 2013; McLean \& Rollwagen 2010). A5 captures this conundrum effectively:

No credentials. So you go from police college and you become an expert in your field, you get a million training courses to get where you are. But you walk into university, with all these 20 -year-olds and say, "I'm going to go with that degree program," they say, "okay, [get in] line with all the other kids. You're exactly like everybody else." And they say, "wait a minute, I got a ton of experience I can bring to this. Don't I get any credits for this?" The answer is absolutely not. (A5, June 2016)

Tied to this lack of access to academic credit is the challenge to gain recognition from colleagues in the larger criminal justice system. As A5 continues:

Why do we have homicide detectives basically write questions for the crown attorneys to ask the offenders and defence lawyers? They're doing the whole case, but they don't get the recognition for any of that. The lawyers do, but the ones that are doing all the work do not. So that is just one example I am giving you of why credentialization was important to them, be- 
cause they felt that all this experience they had in law wasn't being recognized by anybody. (A5, June 2016)

A5 thus evokes how the police sought a credential to elevate the status of their policing-based knowledge and expertise, a reflection of Collins's (1979) credentialing theory as a result of competition among status groups, in this case, the police against crown attorneys and defence lawyers. Importantly, while police received copious training from both municipal and provincial training colleges, these did not provide any academic credit nor were recognized by external institutions. As B2 describes:

If you leave an organization to get an education, you're being assessed by...an academic institution... that has standards set by a different ministry, and I think that all of those things show that you have a stated level of understanding of core topics, whatever they are. In this case, Justice Studies. And in doing that, what I mean by public trust, it's showing that value back to the community, back to the public, by saying these officers have gone out and gotten this degree through this other process. So we talk about professionalizing in policing, and I think it's really important. Professionalization will only occur when you have outside agencies involved in the process of learning in higher education, and particularly with respect to assessment. Assessment of individuals, and assessment of the program itself. So I think it speaks to legitimacy. (B2, January 2017)

Indeed, B2 links gaining academic education to the TPS organizational imperative of professionalization, echoing Barrett's (2010) comment of how assessment by an external assessment, such as an university, would enhance the legitimacy of police education in the eyes of the public. A5 describes:

[The TPS] were saying, "how do we professionalize?" And also, at that time, there were a lot of issues, an inquest was going on, fatal shootings, and one of the things the jury kept coming back with is, "So what's your level of education? What training have you got?" Like, you have these people running divisions! Most unit commanders, to give you an idea, are like little CEOs of their own companies. So any police station, you look around and say, who's the unit commander there? That unit commander probably has a \$48$\$ 60$ million-dollar budget. So here are people with a college or high-school diploma, running a company with so many employees and a huge budget. So the question kept being raised about their education level, who are these people? So without education, they weren't really legitimized. (A5, June 2016)

Hence, to enhance professionalization, legitimacy and recognition, the TPS was seeking an accredited higher education pathway for its senior members. At the time, during the late 1990s-early 2000s, there was growing change in the higher educational marketplace in Ontario. Part of this reflects increasing credentialization, but also provincial recognition to improve access to higher education. In part, this was spurred by the elimination of Grade 13 in Ontario and the creation of a double cohort-a ballooning of high school graduates entering postsecondary institutions (Burt, 2007). To create capacity, the province provided new funding for capital projects and to encourage partnerships between existing institutions, such as colleges and universities (Burt, 2007). In addition, in 2000, Ontario began to allow community colleges to offer four-year undergraduate degree programs (Hurley \& Sá, 2013). Also involved was the growing recognition that prospective higher education students were keen on educational programs that would expand their employability in a volatile, uncertain knowledge-based labour market (Nauffal \& Skulte-Ouaiss, 2018; Pavlin \& Svetlick, 2014; Tomlinson, 2008; Waters, 2009).

One such institution that emerged at that time, being founded in 2002, was the University of Guelph, which was effectively a partnership between Humber College ${ }^{1}$, in west Toronto, and the University of Guelph, in Guelph, Ontario. The University of Guelph-Humber would offer students the opportunity to earn a Humber College diploma and a University of Guelph degree in a limited number of programs in four years, with the selling point being that students would obtain the academic rigour of university and the applied, job-ready skills from college in the same time that it would ordinarily take to complete a university degree. While the story of the Humber-Guelph collaboration has been told elsewhere (Burt, 2007; Ellis, 2005; Hanna, 2016), it is vital to note how this higher education innovation provided a template for creating a pathway for police education, starting with the significant development of collaboration between Humber College and University of Guelph educational administrators. Also pivotal was that retired senior officers from the TPS 
who had pursued higher education became involved in this collaboration. Moreover, the then police chief of the TPS led the creation of a fund to help pay for the higher education of TPS officers at the level of sergeant and above (A5, June 2016). At the onset, TPS was committed to offering $100 \%$ reimbursement for tuition and textbooks for senior officers, and $50 \%$ reimbursement for others (B1, June 2016). Yet, even with a supportive chief and funding allocation, there still needed to be an accredited higher educational pathway. So, the TPS put out an RFP (request for proposals) to colleges and universities to partner with them to create a higher education opportunity for its senior officers (B1, June 2016). The winning proposal came from the nascent University of Guelph-Humber.

However, police officers were not going to take four years out of their careers to pursue an undergraduate degree. So, there needed to be other key developments in order to initiate the pathway. First, there had to be a determination of what aspects of prior police and training and education could qualify for academic credit. This process, known as PLAR, involved mapping learning outcomes from police training against college and then university courses at Humber College and the University of Guelph-Humber, as A6 describes:

I took all of the learning outcomes in the degree and diploma. So the Guelph Justice Studies [Bachelor of Applied Arts in Justice Studies] degree and our [Humber] diploma. I mapped it against all of the work that [the police] did formally and informally at the police college. And when they were on the road, so whatever in-service training that happened until they were first-class constables. The PLAR process requires you to prove that they have achieved those learning outcomes through either formal or informal means. And that can be done through mapping. (A6, October 2016)

In the process of mapping learning outcomes, educational administrators were able to design a process

whereby the officers could get a maximum of $75 \%$ of the diploma in advance, and then we created a program for them to get the remaining $25 \%$. There is a residency requirement in Ontario for the colleges that requires someone to do $25 \%$ of their program at the home institution. So we knew that they had to do $25 \%$ as a minimum. So we mapped out all those learning outcomes and first, mapped the diploma in from the police learning into the diploma, and then, we created a similar process from the diploma into the Guelph-Humber degree, the Justice Studies degree. (A6, October 2016)

Effectively, the University of Guelph-Humber proposed an accredited learning pathway that would allow eligible police officers to achieve most of a Humber College diploma first and then eventually transfer into a university program at the University of Guelph-Humber. In addition to earning PLAR, those who had "a diploma that had any type of academic rigour to it, from any college, a full twoyear diploma" (A3, June 2016), would be given credit for it. Moreover, they would receive credit for the "senior police administration course or the executive development course" toward the two-year college diploma (A3, June 2016). As A1 explains, "we gave [the Toronto Police officers] credit for their orientation training they did when they were hired, training at the Ontario Police College... they ended up getting nine credits, so if they got nine credits, they were going to need eleven more: two year full-time study" (A1, June 2016).

Notably, however, at that time, "college credits were almost impossible to transfer into university credits" (A8, November 2016). However, that began to change, when "universities who ran into some economic issues and recognized that there were some financial gains to be made and enrollment gains to be made by tapping into the college market, students who have some college credits" (A8, November 2016).

The program that was at the centre of the contract between the TPS, Humber College and the University of Guelph was known as the Bachelor of Applied Arts (BAA) in Justice Studies. Since a diploma was still needed to be eligible to be admitted to the BAA, educational administrators created a specific diploma at Humber, the Police Foundations Leadership Program (PFLP). As A6 discussed earlier, with generous PLAR credit for police education and training, they would get " $75 \%$ of the diploma. Then, they were required to take seven [college] courses to make up the rest of [the diploma]" (A6, October 2016). In order to facilitate a course-delivery mechanism that would allow students to maintain their job duties and positions, the BAA was designed with hybrid delivery, with face to face courses over two weekends that bookended six weeks of online instruction. The first 
cohort began in 2005-06 with some years having two cohorts simultaneously. At the time of writing, there have been approximately 20 cohorts.

Almost for the start, the BAA program proved to be highly desirable. As successive waves of TPS senior personnel moved through the program, others clamoured to be admitted. Effectively, TPS had innovated a new pathway for other police services also looking to deepen and extend their professionalization and confer greater credibility and legitimacy of their members. These included, first, members of neighbouring police services in the Greater Toronto Area. However, an emerging dilemma was the homogeneity of the student body and the tendency of groupthink, which I discuss elsewhere (Deckha, 2019). As A3 put it, "If you have one police service, the same police service and the same students in the room, and even some of the faculty were former police officers from the police service, um, you end up with group-think, the danger of group-think" (A3, June 2016).

So, the educational administrators decided on strategies to open up program access. After inviting non-TPS officers to enrol, the next group to join student cohorts were civilians, the non-uniformed, who were not sworn officers. Police officers in Ontario are required to undergo specific kinds of training at the Ontario Police College, that were given PLAR as potential students in the BAA program. Civilians, because of the range and diversity of their work in a police service; e.g., human resources, financial and legal services, communications, etc., did not have specified and uniform training requirements. As a result, the "civilians had a more individualized PLAR" (B1, personal communication, June 2016). Part of the eventual agreement to accept civilians, additional courses were added to the program "to make up for what they don't have now" (A5, June 2016).

Once civilians were added to the student mix, administrators recognized that there was even greater potential to expand and re-imagine the BAA program. Indeed, A4 stresses that the program could not rely on TPS for recruitment purposes forever:

It is not that the Toronto Police doesn't support the program. They still do. They are a great partner but they have more and more of their people that have gone through it. They hired more and more people already with a degree so the candidate pool is becoming less and less, and other institutions have seen the value of the BAA, and they are now are sending their students. So whether it's the RCMP [Royal Canadian Mounted Police], York, Peel, Barrie, Kingston. And, we've also now expanded the program beyond just police officers into anyone involved in the justice system at large. So we have people involved in corporate security, in intelligence, in military people, in court workers, investigators, insurance investigators, youth workers, addiction counsellors, people that are dealing with people who are in conflict with the law, corrections. (A4, June 2016)

The BAA program has recently responded to government signalling "that there should be closer collaboration between the emergency services" (A3, June 2016), which, in Ontario, also includes fire services and emergency medical services. $A 6$ describes how the

Association of Fire Chiefs came to me and said..., "What can we do, we want the same [as the police]... we want to professionalize," the same message...I met with [educational administrators at the University of Guelph-Humber] and I said, here is another group of people...and, we have evolved and created some new courses in the curriculum that would be appropriate for them as members of the fire services. We also changed the name of the program to Justice and Public Safety. (A6, October 2016)

In terms of the new courses created, A3 describes "a shift from a pure academic and the justice-social area [to] a mix of management-type courses, where we're going to be adding four different courses, predominantly online to create more of an online presence" (A3, October 2016). The new program, the BAA in Justice and Public Safety launched officially in fall 2017.

Interestingly, the broadening of the program to incorporate those working in the related fields of public safety reiterates the themes of the benefits of PLAR, expanding educational access and potentially enhancing professionalization, and perhaps latently, credentialization, legitimacy and credibility. Moreover, the expansion to incorporate those from other public safety fields extends the discussion of professionalization and credentialization beyond policing. It also confirms DiMaggio and Powell's (1983) assertion that occupational groups seeking to professionalize will seek out to emulate strategies from professional groups that they deem to be legitimate. Indeed, that other "occupations" are asking for 
higher educational access suggests that the TPS's aim to professionalize and credentialize was perceived to be successful. Also at play is a recognition of market educational forces. When the BAA began, there were few competitors. Now, some fifteen years later, there are other options for undergraduate studies in policing in Ontario, such as the fully-online BA in Policing offered by Wilfrid Laurier University and the Bachelor of Police Studies at Georgian College. Indeed, to partially respond to these changing realities, the BAA made its summer semester courses go fully online in 2020.

\section{Discussion}

de Lint (1998) comments about the Ontario government's 1992 Strategic Planning Committee's objective of a Police Learning System. He suggests that it "represents a move to take police learning and professional development out of the purview of the training academy. It does this by establishing a framework by which police agencies may partner with non-police organizations for training/learning delivery" (1998, p. 273). In effect, the partnership between the TPS, Humber Institute for Technology and Advanced Learning and the University of Guelph and the inception of the BAA program at the University of Guelph-Humber ostensibly reflects the expansion of police learning and education beyond the confines of police college training. Yet, the partnership provided TPS senior personnel accredited access to higher education and offered the TPS as a whole greater sense of legitimacy, professionalization and credibility among the public and key constituencies in the criminal justice systems such as crown attorneys and defence lawyers. In order to facilitate this higher education access, the educational administrators at Humber Institute for Technology and Advanced Learning and the University of Guelph mapped learning outcomes between police training and Justice Studies courses, but more significantly, offered PLAR to recognize the professional training experiences that TPS students had already garnered.

While the TPS supported the higher education process by subsidizing tuition and textbook expenses, the BAA was designed in a flexible delivery format to accommodate the needs of adult learners. The TPS sought to legitimate itself by securing a higher education partnership with an accredited, undergraduate program created for it by the University of Guelph-Humber. That program would help fulfill what DiMaggio and Powell (1983) call a "cognitive base produced by university specialists" ( $p$. 152). It included courses designed to offer academic learning in social problems, criminology, organizational behaviour, public policy, gender issues as well as essential competencies in effective writing and more recently, accounting and financial management (see Appendix A: BAA Curriculum). Moreover, the Toronto Police Service's efforts to seek a higher education partnership represent what Suddaby and Viale (2011) observe in how "professionals reconfigure institutions and organizational fields" (p. 424). As Suddaby and Viale argue, "professionals use their expertise and legitimacy to challenge the incumbent order and to define a new, open and uncontested space" (p. 424). That order and space is the field of expanding police professionalization, legitimacy and credibility through the acquisition of a higher education credential, namely, the undergraduate degree.

Eventually, the TPS-BAA partnership grew to a point where an exclusive arrangement was no longer necessary, resulting in BAA administrators seeking ways to expand its cohorts. The program took in officers from other police services, then civilians, and later learners from the larger criminal justice community, spanning border services, private security and investigations, corrections, the military, youth work, counselling and beyond. Most recently, the BAA has changed its designation from one solely focused on Justice to one that encompasses Justice and Public Safety. It did so to better attract fire and emergency service personnel, modified its course offerings and to respond to increased competition in the education marketplace. For its part, while there is no counterpart to the UK College of Policing in Ontario, the TPS has continued to pursue efforts to further enhance professionalization, credibility and legitimacy. Part of this initiative is a new human resources and development strategy called the People Plan (Toronto Police Service, 2017a) and a competency framework to steer the implementation of this strategy (Toronto Police Service, 2017b). Importantly, one of these competencies, "We Develop Ourselves and Others," directly relates to learning and development.

In conclusion, I have aimed to situate this article within the shifting contours of higher education pathways and the increasing recognition of the needs of adult learners and the intensifying debates about police 
officers and higher education, with an eye to explore how a police service aimed to further professionalize and credentialize its members. I have argued that this professionalizing project included aspirations to increase its legitimacy with the public, including credibility and trust. Furthermore, I have illustrated how the TPS also needed a unique higher education structure, which involved significant consideration of police training, work experience and prior learning assessment and recognition.

\section{Acknowledgements}

The research for this study was supported by the University of Guelph-Humber Research Grant Fund.

\section{References}

Abbott, A. (1988). The system of professions: An essay on the division of expert labor. University of Chicago Press.

Ackroyd, S. (1996). Organization contra organizations: Professions and organizational change in the United Kingdom. Organization Studies, 17, 599-621. https://doi.org/10.1177/017084069601700403

Association of Canadian Community Colleges. (2011). Transferability and post-secondary pathways: The role of Canadian colleges and institutes. https:ll www.accc.ca/ftp/pubs/studies/201104TransferabilityReport.pdf

Bartkowiak-Théron, I. (2019). Research in police education: Current trends. Police Practice And Research, 20(3), 220-224. https://doi.org/10.1080/15614263.2 $\underline{019.1598064}$

Bowers, A., \& Bergman, M. (2016). Affordability and the return on investment of college completion: Unique challenges and opportunities for adult learners. Journal of Continuing Higher Education, 64(3), 144-151. https://doi.org/10.1080/07377363.2016.1 $\underline{229102}$

Boyle, M., Gotcher, D., \& Otts, D. (2018). One state's use of prior learning assessment to augment its workforce development agenda. Journal of Continuing Higher Education, 66(1), 54-58. https://doi.org/1 $\underline{0.1080 / 07377363.2018 .1415634}$
Brown, D. K. (2001). The social sources of educational credentialism: Status cultures, labor markets, and organizations. Sociology of Education, 74, 19-34. https://doi.org/ 10.2307/2673251

Burt, N. (2007). The University of Guelph-Humber: A bold initiative in collaborative learning in Ontario's system of postsecondary education [Master's thesis, Athabasca University]. http://dtpr.lib.athabascau. ca/action/download.php?filename=mais/Final\%20 Thesis.pdf

Christopher, S. (2015). The quantum leap: police recruit training and the case for mandating higher education pre-entry schemes. Policing: A Journal of Policy and Practice, 9(4), 388-404. https://doi.org/10.1093/ Police/Pav021

Collins, R. (1979). The credential society: An historical sociology of education and stratification. Academic Press.

Cordner, G. (2016). The unfortunate demise of police education. Journal of Criminal Justice Education, 27(4), 485-496. https://doi.org/10.1080/10511253.2 $\underline{016.1190134}$

Cordner, G. (2019). Rethinking police education in the United States. Police Practice and Research, 20(3), 225-239. https://doi.org/10.1080/15614263.2019.1 $\underline{598066}$

Deckha, N. (2019). How a university program created for the Toronto Police Service encountered the dilemma of groupthink. International Journal of Case Method Research and Application, 31(1), 182-184. http:/l wacra.org

De Lint, W. (1998). New managerialism and Canadian police training reform. Social \& Legal Studies, 7(2), 261-285. https://doi. org/10.1177/096466399800700206

DiMaggio, P. J., \& Powell, W. (1983). The iron cage revisited: Institutional isomorphism and collective rationality in organizational fields. American Sociological Review, 48, 147-160. https://doi.org/ $10.2307 / 2095101$

Ellis, G. W. (2005). Inter-institutional collaboration in Ontario Higher Education: A case study of the diploma-degree Justice Studies program at the 
University of Guelph-Humber [Doctoral dissertation, University of Toronto]. http://cclp.mior.cal files/4112/4674/0736/EllisAbstract.pdf

Evetts, J. (2006). Short note: The sociology of professional groups: New directions. Current Sociology, 54, 133-143. https://doi.org/ 10.1177/0011392106057161

Fielding, N. G. (2018). Professionalizing the police: The unfulfilled promise of police training. Oxford University Press.

Fuller, A. (2001). Credentialism, adults and part-time higher education in the United Kingdom: An account of rising take up and some implications for policy. Journal of Education Policy, 16(3), 233-248. https:/l doi.org/10.1080/02680930110041042

Griffiths, J. (2006). Review of police training, opportunities for improvement: Toronto Police Service. City of Toronto. https://www.toronto.ca/legdocs/mmis/2007/ au/bgrd/backgroundfile-2617.pdf

Hanna, G. (2016). Bridging the educational binary divide: A case in the sustainability of inter-institutional relations [Unpublished doctoral dissertation]. Nipissing University.

Hayward, M. S., \& Williams, M. R. (2015). Adult learner graduation rates at four U.S. community colleges by prior learning assessment status and method. Community College Journal of Research and Practice, 39(1), 44-54. https://doi.org/10.1080/10668926.201 3.789992

Huey, L., Peladeau, H., \& Kalyal, H. (2018). “There's more than one right path to the destination": Does degree type make a difference in police recruiting? Journal of Criminal Justice Education, 29(3), 399413. https://doi: 10.1080/10511253.2017.1398829

Huisjes, H., Engbers, F., \& Meurs, T. (2018). Higher education for police professionals: The Dutch case. Policing: A Journal of Policy and Practice, 14(2), 362-373. https://doi.org/10.1093/Police/Pay089

Hurley, P., \& Sá, C. M. (2013). Higher education policy and legitimacy building: the making of a new academic credential in Ontario. Higher Education Quarterly, 67(2), 157-179. https://doi.org/10.1111/ Hequ.12010
McCann, L., Granter, E., Hyde, P., \& Hassard, J. (2013). Still blue-collar after all these years? An ethnography of the professionalization of emergency ambulance work. Journal of Management Studies, 50(5), 750-776. https://doi.org/10.1111/joms.12009

Mclean, S., \& Rollwagen, H. (2010). Educational expansion or credential inflation? The evolution of parttime study by adults at McGill University, Canada. International Journal of Lifelong Education, 29(6), 739-755. https://doi.org/10.1080/02601370.2010.5 23944

Nauffal, D., \& Skulte-Ouaiss, J. (2018). Quality higher education drives employability in the Middle East. Education + Training, 60(9), 1057-1069. https://doi. org/10.1108/ET-05-2017-0072

Pavlin, S., \& Svetlik, I. (2014). Employability of higher education graduates in Europe. International Journal of Manpower, 35(4), 418-424. https://doi. org/10.1108/IJM-05-2013-0104

Pohler, D., \& Willness, C. (2014). Balancing interests in the search for occupational legitimacy: The HR professionalization project in Canada. Human Resource Management, 53(3), 467-488. https://doi. org/10.1002/hrm.21579

Ramshaw, P., \& Soppitt, S. (2018). Educating the recruited and recruiting the educated: Can the new police education qualifications framework in England and Wales succeed where others have faltered. International Journal of Police Science \& Management, 20(4), 243-250. https://doi. org/10.1177/1461355718814850

Rust, D. Z., \& Ikard, W. L. (2016). Prior learning assessment portfolio completion: Improved outcomes at a public institution. The Journal of Continuing Higher Education, 64(2), 94-100. https://doi.org/10.1080/07 $\underline{377363.2016 .1177871}$

Suddaby, R., \& Viale, T. (2011). Professionals and fieldlevel change: Institutional work and the professional project. Current Sociology, 59, 423-442.

Toronto Police Service. (2017a). Toronto Police Service people plan: 2017-2019. Author. https://www.torontopolice.on.ca/TheWayForward/

Toronto Police Service. (2017b). Core competencies. 
https://www.torontopolice.on.ca/competencies.php

Tomlinson, M. (2008). "The degree is not enough":

Students' perceptions of the role of higher education credentials for graduate work and employability. British Journal of Sociology of Education, 29(1), 49-61. https://doi.org/10.1080/01425690701737457

Travers, N. L. (2012). What is next after 40 years? Part 2: Prior learning assessment: 2012 and after. The Journal of Continuing Higher Education, 60(2), 117-121. https://doi.org/10.1080/07377363.2012.6 88383

Waters, J. L. (2009). In pursuit of scarcity: Transnational students, "employability," and the MBA. Environment and Planning A, 41(8), 1865-1883. https://doi. org/10.1068/A40319

Williams, E., Norman, J., \& Rowe, M. (2019). The police education qualification framework: A professional agenda or building professionals? Police Practice and Research, 20(3), 1-14. https://doi.org/10.1080/1 $\underline{5614263.2019 .1598070}$

Wood, D. A., \& Tong, S. (2009). The future of initial police training: A university perspective. International Journal of Police Science and Management, 11(3), 294-305.

Wood, J. (2000). Reinventing governance: A study of transformations in the Ontario Provincial Police [Doctoral dissertation, University of Toronto]. https:/l www.collectionscanada.ca/obj/s4/f2/dsk2/ftp03/ NQ49843.pdf

\section{Contact Information}

Nitin Deckha

nitin.deckha@guelphhumber.ca

\section{Notes}

1 On February 10, 2003, Ontario's Ministry of Training, Colleges and Universities designated Humber College as an Institute of Technology and Advanced Learning. This designation would enable the former college to develop and offer bachelor degrees. 


\section{Appendix A: BAA Curriculum}

\section{BAA in Justice Studies}

Fall - Year 1

AHSS 1210 Reading and Writing Effectively

AHSS 1030 Organizational Behaviour

Winter - Year 1

AHSS 3050 Canadian Social Problems

AHSS 3060 Criminological Theory II

Summer - Year 1

SCMA 2040 Research Methods for Social Science

SCMA 3040 Quantitative Methods for Social Science

Fall - Year 2

JUST 3040 Police and Society

JUST 4000 Advanced Issues in Community Policing

Winter - Year 2

AHSS 4100 Public Policy: Challenges and Prospects

AHSS 4090 Ethics and the Justice System

Summer - Year 2

AHSS 3230 Trends in Gender Issues

BADM 2000 Human Resources Management

BAA in Justice and Public Safety - effective Fall 2017

Fall - Year 1

AHSS 1210 English I: Reading and Writing Effectively

AHSS 1030 Organizational Behaviour

Winter - Year 1

AHSS 3050 Canadian Social Problems

JUST 3010 Conflict Resolution

Summer - Year 1

One of:

JUST 2100 Introduction to Justice and Public Safety Accounting

AHSS 3060 Criminological Theory II

One of:

JUST 2090 Introduction to Justice and Public Safety Hu- man Resources Management

JUST 3040 Police and Society

Fall - Year 2

SCMA 2040 Research Methods for Social Science

SCMA 3040 Quantitative Methods for Social Science

Winter - Year 2

AHSS 4100 Public Policy: Challenges and Prospects

AHSS 4090 Ethics and the Justice System

Summer - Year 2

AHSS 3230 Trends in Gender Issues

AHSS 4070 Issues in Ethnicity and Class

All applicants who have not received training at the OPC, the Military Depot, the RCMP depot, or a similar credited government training institution as determined by the University will need to complete the following additional courses listed below:

Fall - Year 3

JUST 1050 Introduction to Industrial Relations

AHSS 2310 Leadership and Motivation

Winter - Year 3

General Elective

General Elective 